DOI: 10.17707/AgricultForest.64.1.07

\author{
Dragana LALEVIĆ, \\ Miodrag JELIĆ, Milan BIBERDŽIĆ ${ }^{1}$
}

\title{
EFFECT OF GENOTYPE AND YEAR ON THE PARAMETERS OF WINTER TRITICALE PRODUCTIVITY CULTIVATED IN NORTHERN MONTENEGRO
}

\begin{abstract}
SUMMARY
This paper presents the results of the impact of fertilization and genotype on fertility parameters of winter triticale. The experiment tested five genotypes of winter triticale (Odisey, Kg-20, Triumph, Rtanj and Tango) from different breeding. The genotypes were grown in the north of Montenegro, in Bijelo Polje (Sutivan) over three growing seasons (2009-2012). The researches were carried out on the river alluvium soil type on an experiment designed by randomized block design with three replications.

The assessment of winter triticale genotypes was based on the analyzed quantitative and qualitative indicators of productivity (number of grains per spike, 1000 grain mass, hectoliter mass and grain yield). In all three years of the study, genotype Tango had the highest grain yield (5.99 t ha ${ }^{-1}$ ), while the lowest yield was observed in genotype Kg-20 (4.48 $\mathrm{t} \mathrm{ha}^{-1}$ ). Also, Tango genotype had the highest value of 1000 grain mass (50.9 g), while the highest hectoliter mass was achieved in genotype Triumph $(71.66 \mathrm{~kg})$. The results showed that meteorological conditions, in the three tested years, had a great influence on the yield and quality. The lack of precipitation and extreme temperatures in the third year caused the abrupt termination of grain filling stages which led to a decline in yield and grain quality. The results of these studies would be valuable in terms of its growing as forage crop as well as in terms of its breeding for grain quality and productivity.
\end{abstract}

Keywords: triticale, genotype, fertilization, 1000 grain mass, hectolitre mass, yield.

\section{INTRODUCTION}

Although triticale species had a short development being created by a man,it recently became an important cereal in the world occupying about 4 million ha, of which over $70 \%$ in Europe. New varieties of triticale are equal or superior to other cultures for grain yield, forage and biomass production for human food, animal feed or industrial applications (Nefir and Tabără, 2011). Modern triticale cultivars show higher yields and good adaptation to different soil and environments than wheat. Also, it is suitable for cultivation at higher

\footnotetext{
${ }^{1}$ Dragana Lalević, (corresponding author: dragana.lalevic@gmail.com), Miodrag Jelić, Milan Biberdžić, University in Pristina, Faculty of Agriculture, Kopaonička bb, 38219 Lešak, SERBIA Paper presented at the $8^{\text {th }}$ International Scientific Agricultural Symposium "AGROSYM 2017". Notes: The authors declare that they have no conflicts of interest. Authorship Form signed online.
} 
altitudes, the soils with poorer physical and chemical properties, saline and acidic soils with a pronounced resistance to biotic and abiotic stresses (Villegas et al., 2010).

Technological quality of triticale is a very complex character, which depends on the genetic potential of cultivars, production practices and agroecological conditions (Zečević et al., 2010). Djekic et al., (2013) report that the yield and the yield components of winter triticale significantly vary depending on the system of processing, the applied doses of nitrogen, the genotype and the year conditions, as well as their complex characteristics. Many authors have reported positive effect of $\mathrm{N}$ fertilization on grain yield (Gibson et al., 2007; Lestingi et al., 2010). Although Kastori et al., (2005) reported that among the elements of mineral nutrition nitrogen plays a major role in increasing the yield, the results expressed by Zečević et al., (2010) and Lalević (2015) show that nitrogen exerts the greatest effect when used together with phosphorus and potassium. The impact of $\mathrm{N}$ fertilizers on cereal yield, yield components and grain quality depends not only on the fertilization strategy but also on the weather conditions (Janušauskaite, Šidlauskas, 2004; Gibson et al., 2007; Pecio, 2010.)

Studying the parameters of fertility of the five selected genotypes of triticale was carried out in order to identify those genotypes achieving the best results in the given production area. Also, the study results on the varieties selected should make a practical and theoretical contribution to the triticale growing technology.

\section{MATERIAL AND METHODS}

The three-year investigations were conducted in Sutivan (the Municipality of Bijelo Polje, north Montenegro), on the alluvial type of soil. Three factorial field microtrials were set up in a randomized block system with three replications. The research included five triticale genotypes created in different selection center (Odisey, Kg-20, Triumph, Rtanj and Tango). Common technology for the production of triticale was used in the experiment. Sowing was carried out by manual method in optimal sowing date (October). The other technology of production which was applied in the experiment was standard, with using NPK fertilizer, in combination 120:80:80. Complex NPK fertilizer (15:15:15) was applied and Calcium-ammonium-nitrate (KAN - 27\%) was applied as nitrogen fertilizer in early spring.

The total amount of phosphorus and potassium fertilizers, together with one third of nitrogen, were used in the pre-sowing soil preparation, while the remaining amount of nitrogen was applied in one topdressing in the early spring. The harvest was also conducted manually at the stage of full maturity, where the 1000 grain mass was measured, as well as the hectoliter weight, and the grain yield was corrected for $14 \%$ moisture.

The average results of the yield of dry grain, hectoliter weight, 1000 grain mass and protein content, are presented in this paper, for the analyzed period of three years. The obtained results were statistically processed using method of 
variance analysis, whereby the significance of average treatments was tested with LSD test, with significance threshold of 1 and 5\%.

\section{RESULTS AND DISCUSSION}

$\underline{\text { Soil and climatic conditions }}$

The soil on which the experiment was performed is weakly calcareous, the total content of carbonate being $2.4-2.44 \%$. The humus content in the surface layer of the soil is high (3,35-3,96\%), while substitutional and total hydrolytic acidity are quite big ( $\left.\mathrm{pH} \mathrm{u} \mathrm{H} \mathrm{H}_{2} \mathrm{O}=6,61-5,53 \mathrm{u} \mathrm{KCl}=5,01-4,94\right)$. The soil is poor with available phosphorus (5.12 - $4.24 \mathrm{mg} / 100 \mathrm{~g}$ soil) and potassium (7.5 - 3.8 $\mathrm{mg} / 100 \mathrm{~g}$ soil). The data in Table 1 . for the research period (2009-2012) show that the years, in which the research was carried out, differ in meteorological conditions from the long-term average characteristics of Bijelo Polje.

Table 1. Meteorological data for Bijelo Polje

\begin{tabular}{|c|c|c|c|c|c|c|c|c|c|c|c|}
\hline \multirow[b]{2}{*}{ Year } & \multicolumn{10}{|c|}{ Months } & \multirow[b]{2}{*}{ Sum } \\
\hline & $\mathrm{X}$ & $\mathrm{XI}$ & XII & $\mathrm{I}$ & II & III & IV & $\mathrm{V}$ & VI & VII & \\
\hline \multicolumn{12}{|c|}{ Monthly rainfall (mm) } \\
\hline 2009-10 & 135 & 94 & 94 & 101 & 80 & 70 & 78 & 80 & 63 & 86 & 881 \\
\hline 2010-11 & 65 & 131 & 147 & 36 & 76 & 31 & 46 & 121 & 33 & 79 & 765 \\
\hline 2011-12 & 36 & 7 & 55 & 79 & 183 & 57 & 47 & 46 & 34 & 8 & 552 \\
\hline 1961-90 & 80 & 1115 & $\overline{991}$ & 87 & 268 & 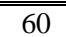 & $\overline{770}$ & 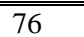 & $\overline{772}$ & 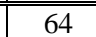 & 783 \\
\hline \multicolumn{12}{|c|}{ Average monthly temperatures $\left({ }^{\circ} \mathrm{C}\right)$} \\
\hline 2009-10 & 9.77 & 5.95 & 4.06 & 1.31 & 2.4 & 6.39 & 10.93 & 15 & 18.11 & 20.95 & 9.5 \\
\hline $2010-11$ & 10.12 & 8.54 & 2.05 & -0.65 & 0.94 & 6.03 & 10.54 & 14.5 & 18.9 & 21.23 & 9.2 \\
\hline 2011-12 & 9.3 & 3.25 & 2.17 & -1.72 & -3.52 & 5.96 & 10.8 & 15.02 & 20.67 & 24.63 & 8.7 \\
\hline 1961-90 & 9.4 & 4.7 & 0.2 & -1.3 & 0.7 & 4.9 & 9.0 & 13.3 & 16.3 & 17.9 & 7.5 \\
\hline
\end{tabular}

The average air temperature in all three years of the study was higher compared to the multiannual average, while the rainfall in 2009/10 was higher for $98 \mathrm{~mm}$, and lower in $2010 / 11$ and $2011 / 12$ for $18 \mathrm{~mm}$, or $213 \mathrm{~mm}$ in relation to the multiannual average. In the first year of study (2009/10), the average air temperature was increased by $2.0^{\circ} \mathrm{C}$ compared to the average of several years. The average air temperature in $2010 / 11$ and $2011 / 12$ was $1.7^{\circ} \mathrm{C}$ and $1.2^{\circ} \mathrm{C}$ higher in comparison to the perennial average. Considerable less rainfall in November 2011, heavy snowfall in February 2012 and significantly higher air temperature in July of the same year, adversely affected the development of plants which resulted in lower yields compared to the first two years of the study.

The data about the achieved number of grains per spike, 1000 grain mass, grain density and grain yield of the studied genotypes of triticale, during the three-year test period, are shown in Table 2. The results of our study show that the genotype and meteorological conditions during the research, expressed different character and intensity of the observed effects on productivity parameters. Numbers of grains per spike represent quite a trait that is largely dependent on agro-ecological conditions, and the applied agro-technology (Jaćimovic et al.,2012). The average values show that the lowest number of 
grains per spike had genotype Triumph (28.3), while the largest number of grains per spike had Odysseus (36.3). With the exception of genotype Tango, where no statistically significant difference was noted, genotype Odysseus compared to others involved in the study had a larger number of grains per spike and the difference was at 0.01 level of significance. The analysis of the average number of grains per spike of the tested genotypes of triticale in the observed years, regardless of the genotype, shows that the lowest average number of grains per spike was in 2010/11 (31.4), and the highest in 2011/12 (33.7)

Table 2. Values of the tested productivity parameters of winter triticale

\begin{tabular}{|c|c|c|c|c|}
\hline & & Year & & \\
\hline Variety & $2009 / 10$ & 2010/11 & $2011 / 12$ & Average \\
\hline \multicolumn{5}{|c|}{ Number of grains per spike } \\
\hline Odisej & 31,8 & 32,1 & 45,5 & 36,5 \\
\hline Kg-20 & 30,8 & 31,8 & 30,0 & 30,9 \\
\hline Trijumf & 28,1 & 27,2 & 29,7 & 28,3 \\
\hline Rtanj & 34,0 & 34,7 & 28,6 & 32,4 \\
\hline Tango & 41,8 & 31,8 & 34,8 & 36,2 \\
\hline Average & 33,3 & 31,4 & 33,7 & 32,9 \\
\hline LSD 0,05 & 1,277 & 1,623 & 1,551 & 2,900 \\
\hline LSD 0,01 & 1,811 & 2,303 & 2,199 & 4,113 \\
\hline \multicolumn{5}{|c|}{1000 grain mass (g) } \\
\hline Odisej & 49,3 & 42,5 & 46,3 & 46,1 \\
\hline Kg-20 & 38,5 & 35,0 & 33,6 & 35,7 \\
\hline Trijumf & 48,3 & 42,7 & 45,0 & 45,3 \\
\hline Rtanj & 49,7 & 47,3 & 44,3 & 47,2 \\
\hline Tango & 54,1 & 49,6 & 48,8 & 50,9 \\
\hline Average & 47,9 & 43,4 & 43,6 & 45,0 \\
\hline LSD 0,05 & 0,859 & 1,271 & 0,975 & 1,436 \\
\hline LSD 0,01 & 1,218 & 1,802 & 1,383 & 2,036 \\
\hline \multicolumn{5}{|c|}{ Hectoliter weight (kg) } \\
\hline Odisej & 73,72 & 69,35 & 69,55 & 70,87 \\
\hline Kg-20 & 66,79 & 63,65 & 64,85 & 65,09 \\
\hline Trijumf & 75,64 & 70,55 & 68,80 & 71,66 \\
\hline Rtanj & 65,86 & 64,39 & 67,10 & 65,78 \\
\hline Tango & 71,09 & 69,30 & 66,30 & 68,90 \\
\hline Average & 70,62 & 67,45 & 67,32 & 68,46 \\
\hline LSD 0,05 & 0,985 & 0,819 & 1,312 & 2,175 \\
\hline LSD 0,01 & 1,394 & 1,161 & 1,605 & 3,070 \\
\hline \multicolumn{5}{|c|}{ Grain yield $\left(\mathrm{t} \mathrm{ha}^{-1}\right)$} \\
\hline Odisej & 5,51 & 4,97 & 4,08 & 4,85 \\
\hline Kg-20 & 5,25 & 4,45 & 3,79 & 4,48 \\
\hline Trijumf & 6,16 & 5,37 & 4,56 & 5,37 \\
\hline Rtanj & 5,96 & 5,62 & 4,49 & 5,36 \\
\hline Tango & 6,95 & 6,05 & 4,97 & 5,99 \\
\hline Average & 5,96 & 5,29 & 4,38 & 5,21 \\
\hline LSD 0,05 & 0,117 & 0,107 & 0,093 & 0,342 \\
\hline LSD 0,01 & 0,166 & 0,152 & 0,132 & 0,485 \\
\hline
\end{tabular}


During the three-year research, genotype Tango had the highest average 1000 grains mass (50.9g). The average three-year value of a 1000 grain mass in genotype Tango was very significantly higher compared to the values observed in other tested genotypes. The highest 1000 grain mass in tested genotypes of triticale was achieved in the first year of study (47.9g), while the lowest was in the second year of study (43.4g). The average values of the 1000 grains mass obtained in this study were somewhat higher compared to the values of this characteristic obtained by Kondić (2009), Lalević et al., (2012); Biberdžić et al., (2013). According to Milošev (2000) the 1000 grains mass is the result of complex interactions of varietal specificity, agroecological conditions and the applied technology.

After reviewing the average values of hectoliter weight of the tested genotypes of triticale, regardless of the years, it can be concluded that genotype Kg-20 (65.09 kg) had the lowest average hectoliter weight, while the highest value of the tested characteristics was achieved in genotype Triumph (71.66 kg). The analysis of the average value of hectoliter weight of the tested genotypes of triticale in the observed years, regardless of the genotype, show that the lowest average hectoliter weight was in the third year of study $(67.32 \mathrm{~kg})$, while the highest was in the first year of study $(70.62 \mathrm{~kg})$. The impact of the year on the value of hectoliter weight was also noticed in our research. Accordingly, in the first year, which was the most favorable according to climatic conditions, the highest average value of the hectoliter weight was recorded $(70.62 \mathrm{~kg})$. Numerous authors (Jelić et al., 1998; Stošović et al., 2010; Lalević et al., 2012) have confirmed in their earlier researches that weather conditions may affect the value of hectoliter weight.

The grain yield per unit area is one of the most important factors affecting the profitability and efficiency of production. Several factors are decisive in triticale yields increasing: the genotype, cultural practices, agro ecological conditions, local climatic and soil characteristics, mineral nutrition and adequate protection from plant diseases, pests and weeds (Milovanović et al., 2011).

Genotype Kg-20 had the lowest average grain yield (3.79 $\left.\mathrm{t} \mathrm{ha}^{-1}\right)$ in 2011/12, while Tango had the highest average grain yield $\left(6.95 \mathrm{t} \mathrm{ha}^{-1}\right)$ in 2009/10.

The analysis of the average grain yield of the tested genotypes of triticale in the observed three-year period was highest in genotype Tango $\left(5.99 \mathrm{t} \mathrm{ha}^{-1}\right)$. At the same time it was significantly much higher in comparison to other tested genotypes. The analysis of the average grain yield of the tested genotypes of triticale in the observed years, regardless of the genotype, show that the highest average yield of the tested genotypes of triticale was in the first year $\left(5.7 \mathrm{tha}^{-1}\right)$, while the lowest yield was in the third year of study $\left(4.5 \mathrm{t} \mathrm{ha}^{-1}\right)$. Taking into account the agro-climatic characteristics of the area, which cause the later sowing and later maturing, as well as the average yields that triticale achieves in commercial production, these results are satisfactory for this area. Considerable variation in grain yield depending on the impact of the genotype and the year of 
research was noted by Stošović, 2009; Biberdžić et al., 2012, 2013; Lalević et al., 2012; in their researches.

\section{CONCLUSIONS}

The results of the research of five genotypes of winter triticale in the period 2009-2012 in the north of Montenegro, show that:

- Agroecological conditions of the year and genotype had significant effect on yield and quality characteristics of triticale.

- The lowest number of grains per spike had genotype Triumph (28.3), while the highest number of grains per spike had Odysseus (36.3).

- The highest average value of a 1000 grain mass during the three years of research had variety Tango (50.9g) .

- Variety Triumph in the first and second year of the study achieved the highest value of hectoliter weight, while in the third year the highest value of hectoliter weight had variety Odisey.

- The average yield of tested genotypes of triticale was highest in the first and lowest in the third year of the study.

- In all three years of study the highest grain yield had genotype Tango.

Based on these results, we can conclude that the genotypes Tango, Triumph and Rtanj showed a good adaptability in both parameters of productivity and as such can be recommended in a commercial triticale production in agroecological conditions of northern Montenegro.

\section{REFERENCES}

Biberdžić, M., Jelić, M., Deletić, N., Barać, S., Stojković, S. (2012): Effects of agroclimatic conditions at trial locations and fertilization on grain yield of triticale. Research Journal of Agricultural Science, 44 (1), 3-8.

Biberdžić, M., Jelić, M., Knežević, B., Barać, S., Maksimović, G., Lalević Dragana (2013): The effect of climatic conditions and variety on some morphological and productivity characteristics of triticale. Research Journal of Agricultural Science, 45 (3), 24-29.

Gibson, L. R., Nance, C. D., Karlen, D. L. (2007): Winter triticale response to nitrogen fertilization when grown after corn or soybean. Agronomy Journal, 99: 49-58.

Đekić, V., Staletić, M., Milovanović, M., Đurić, N., Popović,V.(2013): Istraživanje produktivnosti i kvaliteta KG sorti ozimog tritikalea (Study on productivity and quality of the KG winter triticale varieties), Zbornik naučnih radova Instituta PKB Agroekonomik, Vol. 19, br. 1-2, str. 53-60.

Janušaskaitè, D., Šidlauskas, G. (2004): Nitrogen fertilizer efficacy in winter wheat in relation to weather conditions in Central Lithuania. Zemdirbyste-Agriculture, 88 (4): 34-47 (in Lithuanian)

Jaćimović, G., Malešević, M., Aćin, V., Hristov, N., Marinković, B., Crnobarac, J., Latković, Dragana (2012): Komponente prinosa i prinos ozime pšenice u zavisnosti od nivoa đubrenja azotom, fosforom i kalijumom, (Winter wheat yield components depending on the level of nitrogen, phosphorus and potassium fertilization). Letopis naučnih radova, 36(1): 72-80. 
Jelić M., Lomović, S., Milovanović, M.,Maksimović, D. (1998): Proučavanje nekih agrotehničkih mera neophodnih u proizvodnji zrna jarog tritikalea (Study of some agrotechnology measures necessary in grain production of spring triticale). Zbornik radova „Zimska škola za agronome“, vol. 2, No 2, 29-33.

Kastori, R. (2005): Azot-agrohemijski, agrotehnički, fiziološki i ekološki aspekti (Nitrogen-agrochemical, agrotechnical, physiological and ecological aspects), Monografija, Naučni institut za ratarstvo i povrtarstvo, Novi Sad, 1-419.

Kondić, D. (2009): Kvantitativni pokazatelji produktivnosti tritikalea (x Triticosecale Wittmack) u agroekološkim uslovima Banja Luke (Quantitative Indicators of Productivity of Triticale ( $\times$ Triticosecale Wittmack) in Agroecological Conditions of Banja Luka), Agroznanje, vol. 10., br.4., str. 41-49.

Lalević Dragana, Biberdžić, M., Jelić, M., Barać, S. (2012): Some characteristics of triticale cultivated in rural areas, Agriculture \& Forestry, Vol. 58 Issue 2, p27-34.

Lalević Dragana, Biberdžić Milan (2015): Effects of fertilization and variety on yield and yield components of winter triticale, Agriculture and Forestry, Vol. 61, Issue 2: 119-124.

Lestingi, A., Bovera, F., De Gorgio, D., Ventrella, D. and Tateo, A. (2010): Effect of tillage and nitrogen fertilisation on triticale grain yield, chemical composition and nutritive value. J. Sci. Food Agric. 90: 2440-2446.

Milovanović, M., Staletić, M., Đekić, V., Nikolić, O., Luković, K. (2011): Seed production and contribution of KG varieties to biodiversity of small grains in the period 2006-2010.

Economics of Agriculture-Multifunctional Agriculture and Rural Development, Belgrade, EP 2011 (58), SI-1: 103-111.

Milošev, D. (2000): Izbor sistema ratarenja u proizvodnji pšenice (Selection of the system of farming in the production of wheat). Monografija, Zadužbina Andrejević, Beograd, 1-110.

Nefir, P., Tabără, V. (2011): Effect on products from variety fertilization and triticale (Triticosecale Wittmack) in the experimental field from răcăşdia caras-severin country. Res. J. Agric. Sci. 43(4): 133-137.

Pecio A. (2010): Productivity of triticale affected by nitrogen fertilization and weather conditions fertilizer and fertilization, 40: 101-116.

Stošović Dragana (2009): Uporedna ispitivanja važnijih osobina ječma i tritikalea u agroekološkim uslovima Crne Gore (Comparative studies of the important traits of barley and triticale in agroecological conditions of Montenegro). Magistarska teza, 84, Univerzitet u Prištini, Poljoprivredni fakultet, Kosovska Mitrovica-Zubin Potok.

Stošović, D., Biberdžić, M., Jelić, M., Paunović, A., Jovović, Z. (2010): Utjecaj gnojidbe dušikom na prinos i komponente prinosa zrna tritikalea (The effect of nitrogen fertilization on yield and yield components of winter triticale) , Zbornik radova, 45. hrvatski i 5. međunarodni simpozij agronoma, Opatija, Hrvatska, p. 935-939.

Villegas, D., Casadesus, J., Atienza, S., Martos, V., Maalouf, F., Karam, F., Aranjuelo, I.,Nogues, S. (2010): Tritodeum, wheat and triticale yield components under multi-local mediterranean drought conditions. Field. Crops Research, 100: 240248. http://dx.doi.org/10.1016/j.fcr.2009.11.012

Zečević, V., Knežević, D., Bošković, J., Milenković, S. (2010): Effect of nitrogen and ecological factors on quality of winter triticale cultivars. Genetika, 42 (3): 465474. 